\title{
Effect of a Mycotoxin Binder (MMDA) on the Growth Performance, Blood and Carcass Characteristics of Broilers Fed Ochratoxin A and T-2 Mycotoxin Contaminated Diets
}

\author{
Insaf Riahi ${ }^{1}$, Antonio J. Ramos ${ }^{1}$ D, Jog Raj ${ }^{2}$, Zdenka Jakovčević ${ }^{2}$, Hunor Farkaš ${ }^{2}$, Marko Vasiljević ${ }^{2}$ \\ and Anna Maria Pérez-Vendrell ${ }^{3, * \text { (D) }}$ \\ 1 Applied Mycology Unit, Food Technology Department, University of Lleida, UTPV-XaRTA, \\ AGROTECNIO-CERCA Center, Av. Rovira Roure 191, 25198 Lleida, Spain; insaf.riahi1@gmail.com (I.R.); \\ antonio.ramos@udl.cat (A.J.R.) \\ 2 Patent Co, DOO., Vlade Cetkovica IA, 24211 Subotica, Serbia; jog.raj@patent-co.com (J.R.); \\ zdenka.jakovcevic@patent-co.com (Z.J.); hunor.farkas@patent-co.com (H.F.); \\ marko.vasiljevic@patent-co.com (M.V.) \\ 3 Animal Nutrition Department, Institute of Agrifood Research and Technology (IRTA Mas Bové), \\ 43120 Constanti, Spain \\ * Correspondence: anna.perez@irta.cat
}

Citation: Riahi, I.; Ramos, A.J.; Raj, J.; Jakovčević, Z.; Farkaš, H.; Vasiljević, M.; Pérez-Vendrell, A.M. Effect of a Mycotoxin Binder (MMDA) on the Growth Performance, Blood and Carcass Characteristics of Broilers Fed Ochratoxin A and T-2 Mycotoxin Contaminated Diets. Animals 2021, 11, 3205. https://doi.org/10.3390/ ani11113205

Received: 22 September 2021 Accepted: 5 November 2021 Published: 10 November 2021

Publisher's Note: MDPI stays neutral with regard to jurisdictional claims in published maps and institutional affiliations.

Copyright: (c) 2021 by the authors. Licensee MDPI, Basel, Switzerland. This article is an open access article distributed under the terms and conditions of the Creative Commons Attribution (CC BY) license (https:// creativecommons.org/licenses/by/ $4.0 /)$.
Simple Summary: The contamination of feed with mycotoxins is a global concern, resulting in adverse effects on productivity and animal health and, therefore, a great economic loss. Ochratoxin A and T-2 mycotoxins are among the mycotoxins that contaminate animal feed. These mycotoxins could adversely affect the health of broilers, and the most effective method to mitigate the toxic effects of mycotoxins is the use of detoxifying agents. In the present experiment, broiler chickens were allotted into five groups. Group 1 received a non-contaminated diet; group 2 received a non-contaminated diet $+3 \mathrm{~g} / \mathrm{kg}$ of a mycotoxin binder (MMDA); group 3 received a non-contaminated diet $+0.5 \mathrm{mg} / \mathrm{kg}$ OTA $+1 \mathrm{mg} / \mathrm{kg}$ T-2 toxin; group 4 received a non-contaminated diet $+0.5 \mathrm{mg} / \mathrm{kg}$ OTA $+1 \mathrm{mg} / \mathrm{kg}$ T-2 toxin $+1 \mathrm{~g} / \mathrm{kg}$ MMDA; and group 5 received a non-contaminated diet $+0.5 \mathrm{mg} / \mathrm{kg}$ OTA $+1 \mathrm{mg} / \mathrm{kg}$ $\mathrm{T}-2$ toxin $+3 \mathrm{~g} / \mathrm{kg}$ MMDA for 35 days. The results revealed that OTA and T-2 toxin negatively affected the productive parameters and some blood and carcass characteristics of broiler chickens. The addition of the detoxifying agent (MMDA at 1 or $3 \mathrm{~g} / \mathrm{kg}$ feed) to contaminated diets alleviated the adverse effects observed on productivity and the broilers heath related parameters.

Abstract: The present study was conducted to evaluate the efficacy of the feed additive, a novel multicomponent mycotoxin detoxifying agent (MMDA) containing modified zeolite (clinoptilolite), Bacillus subtilis, B. licheniformis, Saccharomyces cerevisiae cell walls, and silymarin, as detoxifiers of $0.5 \mathrm{mg} / \mathrm{kg}(0.5 \mathrm{ppm})$ ochratoxin A (OTA) and $1 \mathrm{mg} / \mathrm{kg}$ (1 ppm) T-2 toxin on broiler chickens. A total of 240 1-old broiler chickens (Ross 308) were randomly distributed into five different dietary treatments: (1) control (non-contaminated diet); (2) non contaminated diet $+3 \mathrm{~g} / \mathrm{kg}$ of MMDA; (3) non-contaminated diet $+0.5 \mathrm{mg} / \mathrm{kg}$ OTA $+1 \mathrm{mg} / \mathrm{kg} \mathrm{T}-2$ toxin; (4) non-contaminated diet + $0.5 \mathrm{mg} / \mathrm{kg}$ OTA $+1 \mathrm{mg} / \mathrm{kg}$ T-2 toxin $+1 \mathrm{~g} / \mathrm{kg}$ MMDA; and (5) non-contaminated diet $+0.5 \mathrm{mg} / \mathrm{kg}$ OTA $+1 \mathrm{~g} / \mathrm{kg}$ T-2 toxin $+3 \mathrm{~g} / \mathrm{kg}$ MMDA. The results showed that, in the starter period, from 1 to 10 days, the presence of OTA and T-2 mycotoxins reduced the consumption of feed and the growth of the broilers, and no effects of the detoxifying product were observed in the productivity of the chickens, at any of the doses tested, compared to the contaminated control (treatment 3). However, in the growing period, the same negative effect of mycotoxins was registered, but a recovery was observed in the consumption of feed and in the weight of the broilers that consumed $3 \mathrm{~g} / \mathrm{kg}$ of the MMDA mycotoxin binder, reaching similar values to those of chickens fed uncontaminated control diets. The presence of mycotoxins in feed led to a reduction in the concentration of total proteins and albumin in blood compared to controls, and the presence of the detoxifying product partially reversed this effect. The breast yield of the chickens fed with mycotoxins was lower than that of the animals fed with the control feed and was not affected by the presence of the product tested, at 1 or $3 \mathrm{~g} / \mathrm{kg}$. The weight of the different organs (liver, gizzard, kidneys, or spleen), the intestinal $\mathrm{pH}$, the 
histology of the small intestine, and oral lesions were not affected by the experimental treatments. In summary, the productive parameters and some blood and carcass characteristics of broiler chickens were impaired by the dietary presence of OTA and T- 2 toxin. The tested product included at 1 or $3 \mathrm{~g} / \mathrm{kg}$ feed in contaminated diets improved performance and seems to be effective in partly counteracting the deleterious effects of the tested mycotoxins.

Keywords: ochratoxin A; T-2 mycotoxin; broiler chickens; mycotoxin binder

\section{Introduction}

Ochratoxin A (OTA) is a naturally occurring mycotoxin produced by the Aspergillus and Penicillium species that can be found as a contaminant of poultry feeds. OTA contamination can occur from cool temperate to tropical regions (Northern and Southern America, Northern and Western Europe, Africa and South Asia) [1].

Dietary contamination by OTA also poses a big risk for animal health and is a food safety concern due to the transfer of this mycotoxin to humans through the food chain $[2,3]$. The European Commission provides a maximum guidance level for OTA of $0.1 \mathrm{mg} / \mathrm{kg}$ in broiler chickens' complete feed [4].

Despite poultry being less sensitive to OTA than swine, possibly due to the higher capacity of OTA excretion compared to other species [5], several reports indicate adverse effects of dietary OTA contamination in broiler chicken performances, such as reduced feed intake, body weight gain, and feed efficiency [6,7]. Furthermore, OTA negatively affects the health status of poultry by the alteration of the biochemical, hematological, and histopathological parameters, as well as their immune functions. OTA also modifies the gut microbiota of poultry, decreasing its richness and diversity [8-11].

T-2 mycotoxin is mainly produced by Fusarium species and belongs to the trichothecenes family. Since data about the occurrence and toxic effects of T-2 toxin are limited, there are indicative levels of the European Commission for the sum of T-2 and HT-2, above which research is needed [4].

In broiler chickens, the toxic effects of T-2 toxin can be manifested by the impairment of performance and immunocompetence, oral lesions, alteration in blood parameters and organ weights, and induce apoptosis in chicken hepatocytes [12-15].

OTA and T-2 toxin combination resulted in additive adverse effects, causing a decrease in body weight and feed intake [16,17], depressed serum concentrations of total protein, lactate dehydrogenase activity [16], and an impairment of immune function in broiler chickens $[18,19]$.

In this context, the use of adequate detoxification programs is highly recommended. The most well-known approach for the prevention of mycotoxins involves the use of inert adsorbents to bind mycotoxins, reducing their bioavailability in the gastrointestinal tract of animals [20-22].

A novel multicomponent mycotoxin detoxifying agent (MMDA) containing a modified zeolite (clinoptilolite), Bacillus subtilis, Bacillus Licheniformis, Saccharomyces cerevisiae cell wall, and silymarin has been developed, which presents adsorption, biotransformation, hepatoprotection, and immunostimulation as modes of action.

Therefore, the objective of this study was to evaluate the efficacy of the mycotoxin detoxifying feed additive (MMDA or MycoRaid) (Patent Co., Subotica, Serbia) [23] as a detoxifier of OTA and T-2 toxin on broilers.

\section{Materials and Methods}

\subsection{Broilers, Diets, and Experimental Design}

A total of 240 1-day-old male chicks (Ross 308) were randomly allotted to 60 battery cages with an available surface of $0.305 \mathrm{~m}^{2}$ and $37 \mathrm{~cm}$ in height. 
The standard lighting program was $24 \mathrm{~h}$ of light for 2 days, $18 \mathrm{~h}$ of light and $6 \mathrm{~h}$ of dark per day until 7 days, and $16 \mathrm{~h}$ of light per day and $8 \mathrm{~h}$ of dark, thereafter. The temperature program was adjusted as follows: $0-2$ days: $32-34{ }^{\circ} \mathrm{C}$; $3-7$ days: $29-31{ }^{\circ} \mathrm{C}$; 2nd week: $26-28{ }^{\circ} \mathrm{C}$; 3 rd week: $23-25^{\circ} \mathrm{C}$; 4 th week: $20-22{ }^{\circ} \mathrm{C}$ and $19-21{ }^{\circ} \mathrm{C}$ afterwards. Chickens were fed starter diets from 1 to 10 days, grower diets from 11 to 21 days, and finisher diets from 22 to 35 days. Basal diets were based on maize, wheat, and soybean meal, and were formulated according the nutrient requirements for Ross 308 [24] strain broilers. The composition and the estimated nutrient content of basal experimental diets are presented in Table 1. Feed and water were provided ad libitum, in an individual frontal linear feeder and two nipple drinkers connected to each cage. There were five dietary treatments, replicated 12 times each with 4 broiler chickens per replicate at the beginning of the experimental period. Broiler chickens were assigned to one of the five treatments of: (1) control (non-contaminated diet); (2) non-contaminated diet $+3 \mathrm{~g} / \mathrm{kg}$ MMDA; (3) non-contaminated diet $+0.5 \mathrm{mg} / \mathrm{kg}$ OTA $+1 \mathrm{mg} / \mathrm{kg}$ T-2 toxin; (4) non-contaminated diet $+0.5 \mathrm{mg} / \mathrm{kg}$ OTA $+1 \mathrm{mg} / \mathrm{kg}$ T-2 toxin $+1 \mathrm{~g} / \mathrm{kg}$ MMDA; and (5) non-contaminated diet $+0.5 \mathrm{mg} / \mathrm{kg}$ OTA $+1 \mathrm{mg} / \mathrm{kg}$ T-2 toxin $+3 \mathrm{~g} / \mathrm{kg}$ MMDA. MMDA mycotoxin binder was provided by Patent Co. (Subotica, Serbia).

Table 1. Formulation and proximate analysis of experimental basal diets.

\begin{tabular}{|c|c|c|c|}
\hline Ingredients (\%) & $0-10 d$ & $10-21 \mathrm{~d}$ & $21-35 d$ \\
\hline Maize & 33.90 & 35.03 & 39.01 \\
\hline Wheat & 20.00 & 20.00 & 20.00 \\
\hline Soybean meal $(48 \% \mathrm{CP})$ & 37.23 & 35.48 & 30.90 \\
\hline Soybean oil & 4.52 & 5.80 & 6.70 \\
\hline DL-methionine & 0.34 & 0.23 & 0.26 \\
\hline L-lysine-HCl & 0.29 & 0.16 & 0.11 \\
\hline L-threonine & 0.13 & 0.07 & 0.05 \\
\hline Calcium carbonate & 1.10 & 0.96 & 0.84 \\
\hline Monocalcium phosphate & 1.51 & 1.33 & 1.19 \\
\hline Sodium chloride & 0.16 & 0.20 & 0.22 \\
\hline Sodium bicarbonate & 0.32 & 0.25 & 0.23 \\
\hline Choline chloride & 0.09 & 0.07 & 0.07 \\
\hline Vitamin-mineral premix ${ }^{1}$ & 0.40 & 0.40 & 0.40 \\
\hline Noxyfeed $^{2}$ & 0.02 & 0.02 & 0.02 \\
\hline \multicolumn{4}{|l|}{ Nutrient content $(\%)$} \\
\hline AME (kcal/kg) & 3000 & 3100 & 3200 \\
\hline Crude protein & 22.5 & 21.50 & 19.50 \\
\hline Ash & 6.33 & 5.90 & 5.41 \\
\hline Crude fiber & 2.48 & 2.43 & 2.34 \\
\hline Crude fat & 6.91 & 8.21 & 9.20 \\
\hline Digestible lysine & 1.34 & 1.19 & 1.03 \\
\hline Digestible methionine & 0.64 & 0.52 & 0.52 \\
\hline Digestible Met + Cys & 0.95 & 0.82 & 0.80 \\
\hline Digestible threonine & 0.87 & 0.78 & 0.69 \\
\hline Digestible valine & 0.96 & 0.93 & 0.84 \\
\hline Digestible arginine & 1.41 & 1.36 & 1.21 \\
\hline Digestible tryptophan & 0.23 & 0.22 & 0.20 \\
\hline Total calcium & 0.96 & 0.87 & 0.79 \\
\hline Total phosphorus & 0.73 & 0.68 & 0.63 \\
\hline Non-phytate phosphorus & 0.48 & 0.435 & 0.395 \\
\hline
\end{tabular}

${ }^{1}$ Vitamin-mineral premix provided the following nutrients per kg of diet: vitamin A, 13,500 IU; vitamin D3, 4800 IU: vitamin E, 67 IU; vitamin B1: 3 mg; vitamin B2, 9 mg; vitamin B6, 4.5 mg; vitamin B12, $16.5 \mu$; vitamin

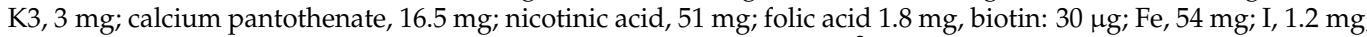
$\mathrm{Co}, 0.6 \mathrm{mg} ; \mathrm{Cu}, 12 \mathrm{mg} ; \mathrm{Mn}, 90 \mathrm{mg} ; \mathrm{Zn}, 66 \mathrm{mg} ; \mathrm{Se}, 0.18 \mathrm{mg} ; \mathrm{Mo}, 1.2 \mathrm{mg} ;{ }^{2}$ Contains BHT+ propyl gallate (56\%), and citric acid (14\%) (ITPSA, Barcelona, Spain).

Ochratoxin A was produced by infecting sterile corn with Aspergillus ochraceus. The infected corn was incubated at $25^{\circ} \mathrm{C}$ for 15 days. T-2/HT-2 was produced by infecting sterile corn with Fusarium langsethiae Fe 2391. The infected corn was incubated at $10^{\circ} \mathrm{C}$ 
for 10 days. The contaminated substrate was then dried on $105^{\circ} \mathrm{C}$ for 2 days, ground, and analyzed using LC-MS/MS.

Before starting the feed production, the three main raw ingredients used were analyzed by Patent Co. (Subotica, Serbia) for the content of the mycotoxins aflatoxins, deoxynivalenol (DON), zearalenone (ZEN), fumonisins (FBs), OTA, T-2 y HT-2 toxins. Soybean meal and wheat presented values for all analyzed mycotoxin below their quantification limits. The maize contained only low contents of Fumonisin $B_{1}(0.64 \mathrm{mg} / \mathrm{kg})$ and Fumonisin $B_{2}$ $(0.22 \mathrm{mg} / \mathrm{kg})$. These ingredients did not contain the mycotoxins under evaluation OTA, or $\mathrm{T}-2$ toxin, and were considered suitable for experimental feeds preparation. Contaminated diets were prepared by adding the culture powder containing OTA and T2 toxin at a level of $1.41 \%$ to the diet to obtain the levels of $0.5 \mathrm{mg} / \mathrm{kg}$ of OTA and $1 \mathrm{mg} / \mathrm{kg}$ of T2 toxin. Experimental diets were analyzed by HPLC for OTA and T-2 toxin, aflatoxins, DON, ZEN, HT-2 toxin, and FBs at Patent Co. (Subotica, Serbia).

\subsection{Productive Parameters}

Chickens were bulk weighed at day 1 and weighed per cage at 10,21, and 35 days. The body weight (BW), body weight gain (BWG), feed intake, and feed to gain ratio in $\mathrm{g}$ feed/g gain (FCR) were calculated for the periods 1-10, 10-21, and 21-35 days, and the overall study. Mortality was checked and recorded daily.

\subsection{Relative Weight of Organs, Breast Meat Yield, and Oral Lesions}

On day 36, a total of 120 animals, 24 chickens per treatment (2 from each replicate or cage), were randomly selected, tagged, and euthanized. Breast, gizzard, liver, kidneys, and spleen were collected and weighed. Breast meat yield and relative organ weights were expressed as a percentage of BW. The oral lesions were assessed using the following score: grade 0 refers to no lesions; grade 1 refers to color of the tongue ash or black; grade 2 refers to lesions with white-yellow plaques; lesions outside buccal cavity (beak, crest, wattle, and eyelids); grade 3 refers to necrotic points, lesions inside buccal cavity (buccal cavity, tongue, tongue papillae, pores of saliva glands); and grade 4 refers to lesions in and outside of cavity.

\subsection{Blood Hematology and Biochemistry}

At day 36, blood samples from one chicken per replicate ( $2 \mathrm{~mL} /$ chicken) were collected by cardiac puncture into non-heparinized tubes for blood hematology and serum biochemistry. The hematological traits were determined using a CELL-DYN 3700 hematology analyzer (Abbott, Chicago, IL, USA), as detailed in Riahi et al. [25]. The heterophil to lymphocyte ratio was evaluated as a measure of stress.

Serum samples were obtained by centrifugation at $1000 \times g$ for $10 \mathrm{~min}$. Total protein, albumin, triglycerides, cholesterol, glucose, aspartate aminotransferase (AST), alanine aminotransferase (ALT), gamma-glutamyl transferase (GGT), and lactate dehydrogenase (LDH) were measured by an automatic biochemical analyzer (Olympus AU5800, Beckman Coulter, Brea, CA, USA).

\subsection{Intestinal $\mathrm{pH}$ and Morphometry}

The $\mathrm{pH}$ of the gastrointestinal content ( 2 chickens/pen) was measured with a portable pH-meter Hanna model HI-9125 (Limena, Italy) and pH electrode Crison model 52-32 (Barcelona, Spain), calibrated before the measurements with buffer solutions at $\mathrm{pH} 4$ and 7 . The $\mathrm{pH}$ of the jejunum content was measured following two procedures: in situ, directly in content of the distal part of jejunum, after insertion of a $\mathrm{pH}$ probe directly into the gut lumen post euthanasia [26], and ex situ, where jejunum digesta was removed and 1/10 dilution with deionized water was performed prior to $\mathrm{pH}$ determination [27].

Intestinal section samples (jejunum) were fixed in a solution of $10 \%$ neutral-buffered formalin at $4{ }^{\circ} \mathrm{C}$. Tissue was sectioned at $4 \mu \mathrm{m}$ thickness (three cross-sections from each sample) and stained with haematoxylin and eosin. Morphometric measurements were 
performed with a light microscope (BHS, Olympus, Barcelona, Spain) as described by Nofrarias et al. [28]. The villus height (VH) and crypt depth (CD) from each segment of each chicken were examined on a linear ocular micrometer (Olympus, 209-35040, Micro Planet, Barcelona, Spain) with a Leica Camera DFC320 (Leica Microsystems Ltd., Wetzlar, Germany) coupled to a computer-based image analysis system LAS v.3.8. (Leica Microsystems Ltd., Wetzlar, Germany). Villus:crypt ratio was calculated by dividing villus height by crypt depth.

\subsection{Statistical Methods}

The basic study design was a randomized complete block design (RCB) of 5 dietary treatments allocated in 12 blocks, with cage location as block criteria. Data were subjected to an analysis of variance to examine the main effect of dietary treatment using the General Linear Model (GLM) procedure of SAS System for Windows V.9.4 (SAS Institute, Cary, NC, USA, 2019). Significant differences were declared at $p \leq 0.05$, while $p$ values between 0.05 and 0.10 were considered a near-significant trend. Tukey's adjustment was applied to perform multiple comparisons of means in case the $\mathrm{F}$ value for treatment in the ANOVA table were significant. In addition, the following linear contrasts were tested: Mycotoxin presence (non-contaminated vs. contaminated): T-1, T-2 vs. T-3, T-4, T-5. Mycotoxin binder at $3 \mathrm{~g} / \mathrm{kg}$ feed: T-1, T-3 vs. T-2, T-5. Binder on contaminated diets: T-3 vs. T-4, T-5.

\section{Results}

\subsection{Analyzed Nutrients and Dietary Mycotoxin Concentrations}

Nutrients and mycotoxins present in the experimental diets are shown in Table 2. The analyzed total protein content of grower and finisher diets was around $0.5 \%$ higher than expected values according to feed formulation: $22.08 \%$ and $20.08 \%$ versus $21.5 \%$ and $19.5 \%$, respectively. Regarding mycotoxins, no aflatoxins (<limit of quantification $(\mathrm{LOQ})=0.4 \mu \mathrm{g} / \mathrm{kg}), \mathrm{DON}(<\mathrm{LOQ}=64 \mu \mathrm{g} / \mathrm{kg})$ or ZEN $(<\mathrm{LOQ}=16 \mu \mathrm{g} / \mathrm{kg})$ were found in any of the experimental diets. As expected, according to the level of FBs found in the maize used for feed preparation, these mycotoxins were present in all the feeds (FB1 between 131 and $276 \mu \mathrm{g} / \mathrm{kg}$; FB2 between $<40$ to $88 \mu \mathrm{g} / \mathrm{kg}$ ), but at levels far below those recommended by the European Commission [4]. The analysis of feeds confirmed the presence of OTA in all diets of treatments T-3 to T-5. The expected value was $500 \mu \mathrm{g} / \mathrm{kg}$ and the average analyzed values were 718,536 , and $426 \mu \mathrm{g} / \mathrm{kg}$ for starter, grower, and finisher feeds, respectively. OTA presence in feeds of treatments T- 1 and T- 2 was in all cases lower than the LOQ $(<1.6 \mu \mathrm{g} / \mathrm{kg})$, confirming that no mycotoxin cross-contamination was produced. The results of T-2 toxin in feeds followed the same trend than those observed for OTA. Feeds from treatments T- 1 and T-2 presented values of T-2 toxin below the LOQ $(<9.6 \mu \mathrm{g} / \mathrm{kg})$. The expected content of T-2 toxin in experimental feeds from treatments T-3 to T-5 was $1000 \mu \mathrm{g} / \mathrm{kg}$, and the analyzed values were on average 853,990 , and $1025 \mu \mathrm{g} / \mathrm{kg}$ for starter, grower, and finisher feeds, respectively.

Table 2. Analyzed nutrients (\%) and mycotoxins ( $\mu \mathrm{g} / \mathrm{kg})$ in experimental diets.

\begin{tabular}{cccc}
\hline Item & $\begin{array}{c}\mathbf{0 - 1 0 ~ d} \\
\text { (Starter) }\end{array}$ & $\begin{array}{c}\mathbf{1 0 - 2 1 ~ d ~} \\
\text { (Grower) }\end{array}$ & $\begin{array}{c}\mathbf{2 1 - 3 5 ~ d ~} \\
\text { (Finisher) }\end{array}$ \\
\hline T-1 (analyzed nutrients, \%) & & & 89.43 \\
Dry matter & 88.08 & 88.5 & 20.46 \\
Crude protein & 22.94 & 22.16 & 8.91 \\
Ether extract & 5.75 & 7.82 & 4.99 \\
Ash & 5.47 & 5.93 & $<1.6$ \\
T-1 (analyzed mycotoxins, $\mu \mathrm{gg} / \mathrm{kg})$ & & $<1.6$ & 263.9 \\
OTA 1 & $<1.6$ & 201.5 & 42.16 \\
FB1 & 154.5 & 40.10 & $<9.6$ \\
FB2 & $<40$ & $<9.6$ & $<9.6$ \\
HT-2 toxin & $<9.6$ & $<9.6$ & \\
\hline
\end{tabular}


Table 2. Cont.

\begin{tabular}{|c|c|c|c|}
\hline Item & $\begin{array}{c}\text { 0-10 d } \\
\text { (Starter) }\end{array}$ & $\begin{array}{l}\text { 10-21 d } \\
\text { (Grower) }\end{array}$ & $\begin{array}{c}21-35 \mathrm{~d} \\
\text { (Finisher) }\end{array}$ \\
\hline \multicolumn{4}{|c|}{ T-2 (analyzed nutrients, $\%$ ) } \\
\hline Dry matter & 88.43 & 88.64 & 89.76 \\
\hline Crude protein & 23.02 & 22.31 & 19.78 \\
\hline Ether extract & 6.29 & 7.39 & 8.84 \\
\hline Ash & 5.82 & 5.77 & 5.27 \\
\hline \multicolumn{4}{|c|}{ T-2 (analyzed mycotoxins, $\mu \mathrm{g} / \mathrm{kg}$ ) } \\
\hline OTA & $<1.6$ & $<1.6$ & $<1.6$ \\
\hline FB1 & 150.0 & 190.3 & 259.6 \\
\hline FB2 & $<40$ & $<40$ & 50.3 \\
\hline HT-2 toxin & $<9.6$ & $<9.6$ & $<9.6$ \\
\hline $\mathrm{T}-2$ toxin & $<9.6$ & $<9.6$ & $<9.6$ \\
\hline \multicolumn{4}{|c|}{ T-3 (analyzed nutrients, \%) } \\
\hline Dry matter & 88.61 & 88.57 & 89.58 \\
\hline Crude protein & 22.45 & 21.93 & 19.90 \\
\hline Ether extract & 5.99 & 7.52 & 8.72 \\
\hline Ash & 5.69 & 5.50 & 4.92 \\
\hline \multicolumn{4}{|c|}{ T-3 (analyzed mycotoxins, $\mu \mathrm{g} / \mathrm{kg}$ ) } \\
\hline OTA & 685.3 & 535.4 & 436.1 \\
\hline FB1 & 153.2 & 276.5 & 258.8 \\
\hline FB2 & $<40$ & 79.7 & 88.1 \\
\hline HT-2 toxin & 254.7 & 267.9 & 300.7 \\
\hline $\mathrm{T}-2$ toxin & 827.7 & 951.7 & 985.6 \\
\hline \multicolumn{4}{|c|}{ T-4 (analyzed nutrients, \%) } \\
\hline Dry matter & 88.48 & 88.79 & 89.62 \\
\hline Crude protein & 22.36 & 21.84 & 20.12 \\
\hline Ether extract & 5.80 & 7.45 & 8.72 \\
\hline Ash & 5.88 & 5.44 & 5.00 \\
\hline \multicolumn{4}{|c|}{ T-4 (analyzed mycotoxins, $\mu \mathrm{g} / \mathrm{kg}$ ) } \\
\hline OTA & 749.1 & 600.7 & 441.3 \\
\hline FB1 & 133.3 & 175.6 & 238.9 \\
\hline FB2 & $<40$ & $<40$ & 68.45 \\
\hline HT-2 toxin & 249.2 & 273.7 & 310.4 \\
\hline $\mathrm{T}-2$ toxin & 831.4 & 939.8 & 998.5 \\
\hline \multicolumn{4}{|c|}{ T-5 (analyzed nutrients, \%) } \\
\hline Dry matter & 88.73 & 89.10 & 89.32 \\
\hline Crude protein & 22.53 & 22.15 & 20.16 \\
\hline Ether extract & 5.82 & 7.40 & 8.53 \\
\hline Ash & 5.92 & 5.66 & 5.23 \\
\hline \multicolumn{4}{|c|}{ T-5 (analyzed mycotoxins, $\mu \mathrm{g} / \mathrm{kg}$ ) } \\
\hline OTA & 719.5 & 471.7 & 400.3 \\
\hline FB1 & 131.3 & 191.9 & $247 . .2$ \\
\hline FB2 & $<40$ & 52.2 & 62.3 \\
\hline HT-2 toxin & 256.4 & 311.4 & 334.8 \\
\hline $\mathrm{T}-2$ toxin & 899.6 & 1080 & 1090 \\
\hline
\end{tabular}

${ }^{1}$ OTA, ochratoxin A; FB, fumonisin.

\subsection{Productive Parameters}

The results of productive parameters and mortality are shown in Table 3. In the starter phase (from 1 to 10 days), significant statistical differences between treatments were observed in all the productive parameters evaluated. The linear contrast "mycotoxin" confirmed that broilers fed diets co-contaminated with OTA and T-2 toxin presented lower feed intake $(p=0.0003)$ than chickens fed non-contaminated feeds, and their growth $(p=0.0002)$, and final BW were also statistically lower $(p=0.0002)$. The BW of broilers at 10-d fed contaminated diets was $7.2 \%$ lower in relation to chickens fed non-contaminated feeds (245.3 vs. $264.2 \mathrm{~g}$ ). No effects were observed on broiler performance due to the inclusion of the feed additive MMDA mycotoxin binder, at the level of $1 \%$ or $3 \%$ (Table 3 ). 
The same pattern was observed in performance of broilers during the grower phase, from 10 to 21 days (Table 3). On average, the BW of chickens fed contaminated diets was $6.2 \%$ lower compared to broilers fed non-contaminated feeds (783 vs. $835 \mathrm{~g}$ ) (linear contrast "Mycotoxin", $p=0.0004)$. Statistically significant differences among treatments were obtained in this growing period in feed intake $(p=0.04)$, BWG $(p=0.01)$, and FCR $(p=0.03)$. Dietary treatment had a significant effect on productive parameters of broilers during the finisher period (from 21 to 35 days); feed intake ( $p=0.01)$, BWG $(p=0.0009)$, and FCR $(p=0.0002)$. In this period, the feed additive MMDA mycotoxin binder included in OTA and T2 toxin-contaminated diets (at both 1 or $3 \mathrm{~g} / \mathrm{kg}$ ) significantly improved BWG (76.6 g/day vs. $82.3 \mathrm{~g} /$ day, $p=0.03$ ) and FCR (1.59 vs. $1.54 \mathrm{~g} / \mathrm{g}, p=0.01)$.

Table 3. Effects of feeding ochratoxin A (OTA) and T-2 mycotoxins and the addition of a mycotoxin binder product (MMDA) on broiler chickens performance.

\begin{tabular}{|c|c|c|c|c|c|c|}
\hline Treatment & $\begin{array}{l}\text { Mycotoxins } \\
\text { (mg/kg) }\end{array}$ & $\begin{array}{c}\text { MMDA }^{1} \\
(\mathrm{~g} / \mathrm{kg})\end{array}$ & $\mathrm{BW}^{2}$ & BWG $^{3}$ & Feed Intake & FCR $^{4}$ \\
\hline \multicolumn{7}{|c|}{ Starter } \\
\hline $\mathrm{T}-1$ & Non-contaminated & 0 & $267.8^{a}$ & $22.4^{\mathrm{a}}$ & $27.1^{\mathrm{a}}$ & $1.22^{b}$ \\
\hline $\mathrm{T}-2$ & Non-contaminated & 3 & $260.6^{a b}$ & $21.7^{\mathrm{ab}}$ & $27.1^{\mathrm{a}}$ & $1.25^{\mathrm{ab}}$ \\
\hline $\mathrm{T}-3$ & $0.5 \mathrm{OTA}^{5}+1 \mathrm{~T}-2$ & 0 & $248.4^{\mathrm{ab}}$ & $20.4^{\mathrm{ab}}$ & $25.7^{b}$ & $1.26^{\mathrm{ab}}$ \\
\hline $\mathrm{T}-4$ & $0.5 \mathrm{OTA}+1 \mathrm{~T}-2$ & 1 & $242.0^{b}$ & $19.8^{b}$ & $25.5^{b}$ & $1.30^{\mathrm{a}}$ \\
\hline $\mathrm{T}-5$ & $0.5 \mathrm{OTA}+1 \mathrm{~T}-2$ & 3 & $245.4^{b}$ & $20.1^{b}$ & $25.5^{b}$ & $1.29 \mathrm{ab}$ \\
\hline & SEM $^{6}$ & & 17.74 & 1.77 & 1.48 & 0.06 \\
\hline & $p$-Value & & 0.003 & 0.003 & 0.008 & 0.02 \\
\hline \multicolumn{7}{|c|}{ Linear contrast } \\
\hline \multicolumn{3}{|c|}{ "Mycotoxin": T-1, T-2 vs. T-3, T-4, T-5 } & 0.0002 & 0.0002 & 0.0003 & 0.006 \\
\hline \multicolumn{3}{|c|}{ "3 g/ $\mathrm{kg}$ additive": T-1, T-3 vs. T-2, T-5 } & 0.32 & 0.32 & 0.76 & 0.09 \\
\hline \multirow{2}{*}{\multicolumn{3}{|c|}{ "Additive": T-3 vs. T-4, T-5 }} & 0.46 & 0.46 & 0.64 & 0.15 \\
\hline & & & \multicolumn{4}{|l|}{ Grower } \\
\hline $\mathrm{T}-1$ & Non-contaminated & 0 & $848^{a}$ & $52.7^{\mathrm{a}}$ & $71.5^{\mathrm{a}}$ & $1.35^{\mathrm{b}}$ \\
\hline $\mathrm{T}-2$ & Non-contaminated & 3 & $822^{a b}$ & $51.0^{\mathrm{ab}}$ & $70.8^{a b}$ & $1.39 \mathrm{ab}$ \\
\hline $\mathrm{T}-3$ & $0.5 \mathrm{OTA}+1 \mathrm{~T}-2$ & 0 & $783^{b}$ & $48.6^{\mathrm{ab}}$ & $67.6^{\mathrm{bc}}$ & $1.41^{\mathrm{a}}$ \\
\hline $\mathrm{T}-4$ & $0.5 \mathrm{OTA}+1 \mathrm{~T}-2$ & 1 & $770^{\mathrm{b}}$ & $48.0^{\mathrm{b}}$ & $67.1^{\mathrm{c}}$ & $1.40^{\mathrm{ab}}$ \\
\hline $\mathrm{T}-5$ & $0.5 \mathrm{OTA}+1 \mathrm{~T}-2$ & 3 & $796^{\mathrm{ab}}$ & $49.8^{a b}$ & $69.4^{\mathrm{abc}}$ & $1.40^{\mathrm{ab}}$ \\
\hline & SEM & & 52.1 & 3.56 & 4.04 & 0.04 \\
\hline \multicolumn{3}{|c|}{$p$-Value } & 0.02 & 0.01 & 0.04 & 0.03 \\
\hline & Linear contrast & & & \\
\hline \multicolumn{3}{|c|}{ "Mycotoxin": T-1, T-2 vs. T-3, T-4, T-5 } & 0.0004 & 0.002 & 0.006 & 0.006 \\
\hline \multicolumn{3}{|c|}{ "3 g/ kg additive": T-1, T-3 vs. T-2, T-5 } & 0.65 & 0.80 & 0.64 & 0.29 \\
\hline \multirow{2}{*}{\multicolumn{3}{|c|}{ "Additive": T-3 vs. T-4, T-5 }} & 0.98 & 0.82 & 0.65 & 0.68 \\
\hline & & & Finisher & & & \\
\hline $\mathrm{T}-1$ & Non-contaminated & 0 & $2093^{a}$ & $88.9^{a}$ & $134^{\mathrm{a}}$ & $1.50^{\mathrm{c}}$ \\
\hline $\mathrm{T}-2$ & Non-contaminated & 3 & $2044^{\mathrm{ab}}$ & $87.3^{\mathrm{a}}$ & $133^{\mathrm{a}}$ & $1.53^{b c}$ \\
\hline $\mathrm{T}-3$ & $0.5 \mathrm{OTA}+1 \mathrm{~T}-2$ & 0 & $1855^{c}$ & $76.6^{\mathrm{b}}$ & $123^{b}$ & $1.59^{\mathrm{a}}$ \\
\hline $\mathrm{T}-4$ & $0.5 \mathrm{OTA}+1 \mathrm{~T}-2$ & 1 & 1929 bc & $82.1^{a b}$ & $128^{a b}$ & $1.56^{\mathrm{ab}}$ \\
\hline $\mathrm{T}-5$ & $0.5 \mathrm{OTA}+1 \mathrm{~T}-2$ & 3 & 1939 bc & $82.5^{a b}$ & $126^{\mathrm{ab}}$ & $1.53^{b c}$ \\
\hline & SEM & & 129.2 & 7.25 & 8.89 & 0.041 \\
\hline \multirow{2}{*}{\multicolumn{3}{|c|}{$p$-Value }} & 0.0002 & 0.0009 & 0.01 & 0.0002 \\
\hline & & & Linear contrast & & & \\
\hline \multicolumn{3}{|c|}{ "Mycotoxin": T-1, T-2 vs. T-3, T-4, T-5 } & 0.0001 & 0.0002 & 0.0009 & 0.0004 \\
\hline \multicolumn{3}{|c|}{ "3 g/ $\mathrm{kg}$ additive": T-1, T-3 vs. T-2, T-5 } & 0.65 & 0.31 & 0.59 & 0.24 \\
\hline \multicolumn{3}{|c|}{ "Additive": T-3 vs. T-4, T-5 } & 0.10 & 0.03 & 0.18 & 0.01 \\
\hline
\end{tabular}

${ }^{1}$ MMDA, mycotoxin binder; ${ }^{2} \mathrm{BW}$, body weight; ${ }^{3} \mathrm{BWG}$, body weight gain; ${ }^{4} \mathrm{FCR}$, feed conversion ratio; ${ }^{5} \mathrm{OTA}$, ochratoxin A; ${ }^{6} \mathrm{SEM}$, standard error of mean $(n=12) ;{ }^{a, b, c}$ : means values with different superscripts within the same column differ $(p \leq 0.05)$. 


\subsection{Blood Biochemistry}

The results of biochemistry of blood of broilers at the end of study are presented in Table 4. Statistically significant differences among treatments were found on total proteins and albumin $(p=0.01)$. In the present study, the inclusion of $3 \mathrm{~g}$ of MMDA mycotoxin binder $/ \mathrm{kg}$ feed seemed to revert the mycotoxin deleterious effects improving both values ( $p=0.009$, for total proteins and $p=0.04$, for albumin). The additive at lower dose increased the triglycerides level $(p=0.0008)$ and at higher dose increased the activity of the LDH enzyme $(p=0.05)$. Statistical effects were also observed on the enzymatic AST activity $(p=0.04)$ related to the presence of the mycotoxins.

Table 4. The effects of feeding ochratoxin A (OTA) and T-2 mycotoxins and the addition of a binder mycotoxin product (MMDA) on blood biochemistry of broiler chickens.

\begin{tabular}{|c|c|c|c|c|c|c|c|c|c|c|c|}
\hline Treatment & $\begin{array}{l}\text { Mycotoxins } \\
\text { (mg/kg) }\end{array}$ & $\begin{array}{l}\text { MMDA } \\
1 \text { (g/kg) }\end{array}$ & $\begin{array}{c}\text { LDH } \\
(\mathrm{U} / \mathrm{L})^{2}\end{array}$ & $\begin{array}{c}\text { GGT } \\
(\mathrm{U} / \mathrm{L})^{3}\end{array}$ & $\begin{array}{c}\mathrm{AST} \\
(\mathrm{U} / \mathrm{L})^{4}\end{array}$ & $\begin{array}{c}\text { ALT } \\
(\mathrm{U} / \mathrm{L})^{5}\end{array}$ & $\begin{array}{c}\text { ALB } \\
(\mathrm{g} / \mathrm{L})^{6}\end{array}$ & $\begin{array}{l}\text { Tot prot } \\
\text { (g/L) }{ }^{7}\end{array}$ & ${ }_{(\mathrm{mg} / \mathrm{dL})^{8}}$ & $\begin{array}{c}\text { Chol } \\
(\mathrm{mg} / \mathrm{dL})^{9}\end{array}$ & $\begin{array}{c}\text { Glu } \\
(\mathrm{mg} / \mathrm{dL})^{10}\end{array}$ \\
\hline $\mathrm{T}-1$ & $\begin{array}{c}\text { Non- } \\
\text { contaminated }\end{array}$ & 0 & 1893 & 23.3 & $358^{a}$ & 2.42 & $10.5^{\mathrm{ab}}$ & $28.8^{a b}$ & $76.4^{b}$ & 129 & 252 \\
\hline $\mathrm{T}-2$ & $\begin{array}{c}\text { Non- } \\
\text { contaminated }\end{array}$ & 3 & 1838 & 25.7 & $316^{a b}$ & 2.00 & $11.1^{\mathrm{a}}$ & $30.7^{\mathrm{a}}$ & $76.8^{b}$ & 132 & 249 \\
\hline $\mathrm{T}-3$ & $\begin{array}{c}0.5 \mathrm{OTA}^{11}+1 \\
\mathrm{~T}-2\end{array}$ & 0 & 1407 & 23.5 & $305^{a b}$ & 2.08 & $9.83^{b}$ & $27.2^{b}$ & $71.7^{\mathrm{b}}$ & 126 & 253 \\
\hline $\mathrm{T}-4$ & $\begin{array}{c}0.5 \text { OTA + } 1 \\
\text { T-2 }\end{array}$ & 1 & 1727 & 21.8 & $280^{a b}$ & 2.33 & $10.4^{\mathrm{ab}}$ & $28.6^{a b}$ & $112^{\mathrm{a}}$ & 136 & 259 \\
\hline \multirow[t]{4}{*}{$\mathrm{T}-5$} & $\begin{array}{c}0.5 \text { OTA + } 1 \\
\text { T- } 2\end{array}$ & 3 & 2965 & 25.2 & $254^{b}$ & 2.08 & $10.2^{a b}$ & $28.2^{b}$ & $81.2^{b}$ & 129 & 252 \\
\hline & SEM $^{12}$ & & 1315 & 5.34 & 73.6 & 0.54 & 0.81 & 1.92 & 23.9 & 12.0 & 14.3 \\
\hline & $p$-Value & & 0.07 & 0.43 & 0.04 & 0.28 & 0.01 & 0.01 & 0.0008 & 0.30 & 0.61 \\
\hline & & & & & Linea & ontrast & & & & & \\
\hline \multicolumn{3}{|c|}{ "Mycotoxin": T-1, T-2 vs. T-3, T-4, T-5 } & 0.69 & 0.51 & 0.007 & 0.77 & 0.005 & 0.001 & 0.07 & 0.98 & 0.28 \\
\hline \multicolumn{3}{|c|}{ “3 g/kg additive": T-1, T-3 vs. T-2, T-5 } & 0.06 & 0.20 & 0.07 & 0.19 & 0.04 & 0.009 & 0.48 & 0.40 & 0.63 \\
\hline \multicolumn{3}{|c|}{ "Additive": T-3 vs. T-4, T-5 } & 0.05 & 0.98 & 0.17 & 0.52 & 0.08 & 0.07 & 0.004 & 0.12 & 0.69 \\
\hline
\end{tabular}

${ }^{1}$ MMDA, mycotoxin binder; ${ }^{2}$ LDG, lactate dehydrogenase; ${ }^{3}$ GGT, gamma-glutamyl transferase; ${ }^{4}$ AST, aspartate aminotransferase;

${ }^{5}$ ALT, alanine aminotransferase; ${ }^{6}$ ALB, albumin; ${ }^{7}$ Tot prot, total proteins; ${ }^{8}$ Trig, triglycerides; ${ }^{9}$ Chol, cholesterol; ${ }^{10}$ Glu, glucose; ${ }^{11}$ OTA, ochratoxin $\mathrm{A} ;{ }^{12}$ SEM, standard error of mean $(n=12)$; ${ }^{\mathrm{a}, \mathrm{b}}$ : means values with different superscripts with the same column differ $(p \leq 0.05)$.

\subsection{Blood Hematology}

The results of hematology of blood of broilers at the end of study are presented in Tables 5 and 6. Dietary treatment had no effect on blood count of broilers (Table 5), except for mean corpuscular volume (MCV) $(p=0.04)$. The additive increased the hematocrit value of broilers fed contaminated diets (linear contrast "additive", $p=0.02$ ). The inclusion of increasing levels of the detoxifying product to the mycotoxin contaminated diet produced a progressive increase in the total number of red blood cells (RBC), which was statistically significant at the level of $3 \mathrm{~g} / \mathrm{kg}(p=0.02)$. A significant reduction in the number of monocytes was also observed as the level of the additive increased $(p=0.03)$. Other blood parameters, even heterophil to lymphocyte ratio $(\mathrm{H} / \mathrm{L})$ (related to stress) were not affected by dietary treatments.

Table 5. The effects of feeding ochratoxin A (OTA) and T-2 mycotoxins and the addition of a binder mycotoxin product (MMDA) on blood hematology (blood count) of broiler chickens.

\begin{tabular}{|c|c|c|c|c|c|c|c|c|}
\hline Treatment & Mycotoxins (mg/kg) & $\begin{array}{c}\mathrm{MMDA}^{1} \\
(\mathrm{~g} / \mathrm{kg})\end{array}$ & $\mathrm{HCT}^{2}$ & $\mathrm{Hgb}^{3}$ & $\mathrm{RBC}^{4}$ & $\mathrm{MCV}^{5}$ & $\mathrm{MCH}^{6}$ & $\mathrm{MCHC}^{7}$ \\
\hline $\mathrm{T}-1$ & Non-contaminated & 0 & 30.1 & 13.0 & 2.54 & $118^{a b}$ & 51.2 & 43.6 \\
\hline $\mathrm{T}-2$ & Non-contaminated & 3 & 29.7 & 13.5 & 2.69 & $112^{b}$ & 50.0 & 44.6 \\
\hline $\mathrm{T}-3$ & $0.5 \mathrm{OTA}^{8}+1 \mathrm{~T}-2$ & 0 & 28.2 & 12.4 & 2.50 & $115^{\mathrm{ab}}$ & 49.6 & 43.0 \\
\hline $\mathrm{T}-4$ & $0.5 \mathrm{OTA}+1 \mathrm{~T}-2$ & 1 & 31.6 & 12.8 & 2.54 & $124^{\mathrm{a}}$ & 50.4 & 40.8 \\
\hline \multirow[t]{3}{*}{$\mathrm{T}-5$} & $0.5 \mathrm{OTA}+1 \mathrm{~T}-2$ & 3 & 30.1 & 13.0 & 2.59 & $116^{\mathrm{ab}}$ & 50.1 & 43.4 \\
\hline & SEM $^{9}$ & & 2.87 & 0.97 & 0.18 & 9.32 & 1.53 & 3.65 \\
\hline & $p$-Value & & 0.11 & 0.17 & 0.13 & 0.04 & 0.15 & 0.14 \\
\hline
\end{tabular}


Table 5. Cont.

\begin{tabular}{|c|c|c|c|c|c|c|c|c|}
\hline Treatment & Mycotoxins (mg/kg) & $\begin{array}{c}\mathrm{MMDA}^{1} \\
(\mathrm{~g} / \mathrm{kg})\end{array}$ & $\mathrm{HCT}^{2}$ & $\mathrm{Hgb}^{3}$ & $\mathrm{RBC}^{4}$ & $\mathrm{MCV}^{5}$ & $\mathrm{MCH}^{6}$ & $\mathrm{MCHC}^{7}$ \\
\hline \multicolumn{9}{|c|}{ Linear contrast } \\
\hline \multicolumn{3}{|c|}{ "Mycotoxin": T-1, T-2 vs. T-3, T-4, T-5 } & 0.86 & 0.08 & 0.15 & 0.21 & 0.24 & 0.08 \\
\hline \multicolumn{3}{|c|}{ "3 g/ $\mathrm{kg}$ additive": T-1, T-3 vs. T-2, T-5 } & 0.43 & 0.07 & 0.02 & 0.34 & 0.42 & 0.49 \\
\hline \multicolumn{3}{|c|}{ "Additive": T-3 vs. T-4, T-5 } & 0.02 & 0.16 & 0.31 & 0.16 & 0.23 & 0.46 \\
\hline
\end{tabular}

\footnotetext{
${ }^{1} \mathrm{MMDA}$, mycotoxin binder; ${ }^{2} \mathrm{HCT}$, hematocrit; ${ }^{3} \mathrm{Hgb}$, hemoglobin; ${ }^{4} \mathrm{RBC}$, red blood cells; ${ }^{5} \mathrm{MCV}$, mean corpuscular volume; ${ }^{6} \mathrm{MCH}$, mean cell hemoglobin; ${ }^{7} \mathrm{MCHC}$, mean corpuscular hemoglobin concentration; ${ }^{8}$ OTA, ochratoxin $\mathrm{A} ;{ }^{9} \mathrm{SEM}$, standard error of mean $(n=12)$; $\mathrm{a}, \mathrm{b}$ : means values with different superscripts with the same column differ $(p \leq 0.05)$.
}

Table 6. The effects of feeding ochratoxin A (OTA) and T-2 mycotoxins and the addition of a binder mycotoxin product (MMDA) on blood hematology (leukogram) of broiler chickens.

\begin{tabular}{|c|c|c|c|c|c|c|c|c|c|}
\hline Treatment & Mycotoxins (mg/kg) & $\begin{array}{c}\text { MMDA }^{1} \\
(\mathrm{~g} / \mathrm{kg})\end{array}$ & Leuk $^{2}$ & $\begin{array}{c}\text { EOS }^{3} \\
\%\end{array}$ & $\begin{array}{c}\text { BAS } \\
\%\end{array}$ & $\begin{array}{c}\text { LYM }^{5} \\
\%\end{array}$ & $\begin{array}{c}\text { MON }^{6} \\
\%\end{array}$ & $\begin{array}{c}\text { HET }^{7} \\
\%\end{array}$ & $\mathrm{H} / \mathrm{L}^{8}$ \\
\hline $\mathrm{T}-1$ & Non-contaminated & 0 & 2.28 & 4.42 & 7.75 & 44.4 & $5.58^{\mathrm{a}}$ & 37.8 & 0.83 \\
\hline $\mathrm{T}-2$ & Non-contaminated & 3 & 1.90 & 4.64 & 7.09 & 46.0 & $3.36^{\mathrm{ab}}$ & 38.9 & 1.12 \\
\hline $\mathrm{T}-3$ & $0.5 \mathrm{OTA}^{9}+1 \mathrm{~T}-2$ & 0 & 2.07 & 6.42 & 4.90 & 40.2 & $4.50^{\mathrm{ab}}$ & 45.4 & 1.20 \\
\hline $\mathrm{T}-4$ & $0.5 \mathrm{OTA}+1 \mathrm{~T}-2$ & 1 & 1.84 & 5.83 & 5.42 & 43.5 & $2.58^{b}$ & 42.1 & 1.12 \\
\hline $\mathrm{T}-5$ & $0.5 \mathrm{OTA}+1 \mathrm{~T}-2$ & 3 & 2.07 & 4.25 & 5.25 & 44.8 & $2.82^{\mathrm{ab}}$ & 42.2 & 0.99 \\
\hline & SEM ${ }^{10}$ & & 0.06 & 4.02 & 3.96 & 11.5 & 2.47 & 14.8 & 0.66 \\
\hline & $p$-Value & & 0.52 & 0.82 & 0.41 & 0.85 & 0.03 & 0.78 & 0.76 \\
\hline \multicolumn{10}{|c|}{ Linear contrast } \\
\hline \multicolumn{3}{|c|}{ "Mycotoxin": T-1, T-2 vs. T-3, T-4, T-5 } & 0.61 & 0.44 & 0.07 & 0.59 & 0.06 & 0.30 & 0.66 \\
\hline \multirow{2}{*}{\multicolumn{3}{|c|}{$\begin{array}{l}\text { "3 g/ } / \mathrm{kg} \text { additive": T-1, T-3 vs. T-2, T-5 } \\
\text { "Additive": T-3 vs. T-4, T-5 }\end{array}$}} & 0.31 & 0.43 & 0.54 & 0.45 & 0.03 & 0.85 & 0.84 \\
\hline & & & 0.64 & 0.58 & 0.73 & 0.31 & 0.05 & 0.47 & 0.51 \\
\hline
\end{tabular}

${ }^{1}$ MMDA, mycotoxin binder; ${ }^{2}$ Leuk, leukocytes; ${ }^{3}$ EOS, eosinophils; ${ }^{4}$ BAS, basophils; ${ }^{5}$ LYM, lymphocytes; ${ }^{6}$ MON, monocytes; ${ }^{7}$ HET, heterophils; ${ }^{8} \mathrm{H} / \mathrm{L}$, heterophils to lymphocytes ratio; ${ }^{9} \mathrm{OTA}$, ochratoxin $\mathrm{A} ;{ }^{10} \mathrm{SEM}$, standard error of mean $(n=12) ;{ }^{\mathrm{a}, \mathrm{b}}$ : means values with different superscripts with the same column differ $(p \leq 0.05)$.

\subsection{Breast Meat Yield}

Statistically significant differences among treatments in BW $(p=0.002)$ and breast weight $(p=0.0001)$, and the corresponding linear contrasts confirmed that these differences were mainly related to the dietary presence of mycotoxins (BW, $p=0.0008$; breast meat weight, $p=0.0001)$. When broilers were fed mycotoxin-contaminated diets, the inclusion of the feed additive MMDA mycotoxin binder showed a tendency to improve BW $(p=0.08)$. At 36 days of life, the final BW of chickens fed contaminated diet and $1 \mathrm{~g} / \mathrm{kg}$ was numerically $4.6 \%$ higher than the BW of chickens fed control contaminated feed (1995 vs. $1907 \mathrm{~g}$ ). When the inclusion level of the MMDA mycotoxin binder was $3 \mathrm{~g} / \mathrm{kg}$, the observed body weight increase was $7.3 \%$ (2046 vs. $1907 \mathrm{~g}$ ) (Table 7). A clear effect of the mycotoxins was observed in the percentage of breast meat that was higher (17.5\%) for broilers fed non-contaminated diets compared to chickens that consumed feeds with OTA and T-2 toxin $(15.7 \%)(p=0.0001)$.

Table 7. The effects of feeding ochratoxin A (OTA) and T-2 mycotoxins, and the addition of a binder mycotoxin product (MMDA) on breast meat yield of broiler chickens.

\begin{tabular}{|c|c|c|c|c|c|}
\hline Treatment & Mycotoxins (mg/kg) & $\operatorname{MMDA}^{1}(\mathrm{~g} / \mathrm{kg})$ & $\mathrm{BW}^{2}(\mathrm{~g})$ & Breast Meat Weight (g) & Breast Meat Yield (\%) \\
\hline $\mathrm{T}-1$ & Non-contaminated & 0 & $2199^{a}$ & $385.8^{a}$ & $17.5^{\mathrm{a}}$ \\
\hline $\mathrm{T}-2$ & Non-contaminated & 3 & $2096^{a b}$ & $350.1^{\mathrm{ab}}$ & $16.7^{\mathrm{ab}}$ \\
\hline $\mathrm{T}-3$ & $0.5 \mathrm{OTA}^{3}+1 \mathrm{~T}-2$ & 0 & $1907^{b}$ & $296.1^{c}$ & $15.7^{\mathrm{b}}$ \\
\hline $\mathrm{T}-4$ & 0.5 OTA + $1 \mathrm{~T}-2$ & 1 & $1995^{\mathrm{ab}}$ & $317.1^{b c}$ & $15.8^{\mathrm{b}}$ \\
\hline $\mathrm{T}-5$ & $0.5 \mathrm{OTA}+1 \mathrm{~T}-2$ & 3 & $2046^{\mathrm{ab}}$ & $322.4^{b c}$ & $15.7^{b}$ \\
\hline & SEM $^{4}$ & & 255.8 & 56.32 & 1.78 \\
\hline & $p$-Value & & 0.002 & 0.0001 & 0.0009 \\
\hline
\end{tabular}


Table 7. Cont.

\begin{tabular}{|c|c|c|c|c|c|}
\hline Treatment & Mycotoxins (mg/kg) & $\operatorname{MMDA}^{1}(\mathrm{~g} / \mathrm{kg})$ & $\mathrm{BW}^{2}(\mathrm{~g})$ & Breast Meat Weight (g) & Breast Meat Yield (\%) \\
\hline \multicolumn{6}{|c|}{ Linear contrast } \\
\hline \multirow{2}{*}{\multicolumn{3}{|c|}{$\begin{array}{l}\text { "Mycotoxin": T-1, T-2 vs. T-3, T-4, T-5 } \\
\text { "3 g/kg additive": T- } 1 \text {, T-3 vs. T-2, T-5 }\end{array}$}} & 0.0008 & 0.0001 & 0.0001 \\
\hline & & & 0.73 & 0.69 & 0.29 \\
\hline \multicolumn{3}{|c|}{ "Additive": T-3 vs. T-4, T-5 } & 0.08 & 0.09 & 0.77 \\
\hline
\end{tabular}

${ }^{1}$ MMDA, mycotoxin binder; ${ }^{2}$ BW, body weight; ${ }^{3}$ OTA, ochratoxin A; ${ }^{4}$ SEM, standard error of mean $(n=12) ;$ a,b,c: means values with different superscripts with the same column differ $(p \leq 0.05)$.

\subsection{Relative Weight of Organs and Oral Lesions}

No effects of dietary treatments were observed in the relative weights of gizzard, kidney, or spleen organs, expressed in percentage of body weight, except a tendency in liver weight $(p=0.08$ ) (Table 8). The number of chickens showing oral lesions is also reported in Table 8 . Most of the chickens presented grade 0 (no lesions) and only six chickens presented grade 1 , and no related to the dietary treatment tested. No animals presented grades 2,3 , or 4 .

Table 8. The effects of feeding ochratoxin A (OTA) and T-2 mycotoxins and the addition of a binder mycotoxin product (MMDA) on relative weight of organs and oral lesions in broiler chickens.

\begin{tabular}{|c|c|c|c|c|c|c|c|}
\hline Treatment & $\begin{array}{l}\text { Mycotoxins } \\
\text { (mg/kg) }\end{array}$ & $\begin{array}{c}\text { MMDA }^{1} \\
(\mathrm{~g} / \mathrm{kg})\end{array}$ & $\begin{array}{l}\text { Liver RW } \\
2(\%)\end{array}$ & $\begin{array}{l}\text { Gizzard } \\
\text { RW (\%) }\end{array}$ & $\begin{array}{l}\text { Kidneys } \\
\text { RW (\%) }\end{array}$ & $\begin{array}{l}\text { Spleen } \\
\text { RW (\%) }\end{array}$ & $\begin{array}{c}\text { Oral Lesions Scores } \\
\left(n^{0} \text { Chickens with }\right. \\
\text { Score }=1)^{3}\end{array}$ \\
\hline $\mathrm{T}-1$ & Non-contaminated & 0 & 2.12 & 1.70 & 0.59 & 0.09 & 1 (of 24$)$ \\
\hline $\mathrm{T}-2$ & Non-contaminated & 3 & 2.34 & 1.81 & 0.62 & 0.11 & 2 (of 24$)$ \\
\hline $\mathrm{T}-3$ & $0.5 \mathrm{OTA}^{4}+1 \mathrm{~T}-2$ & 0 & 2.25 & 1.87 & 0.65 & 0.10 & 1 (of 24$)$ \\
\hline $\mathrm{T}-4$ & 0.5 OTA + $1 \mathrm{~T}-2$ & 1 & 2.25 & 1.83 & 0.60 & 0.10 & 0 (of 24) \\
\hline $\mathrm{T}-5$ & $0.5 \mathrm{OTA}+1 \mathrm{~T}-2$ & 3 & 2.18 & 1.83 & 0.62 & 0.09 & 2 (of 24$)$ \\
\hline & SEM $^{5}$ & & 0.27 & 0.24 & 0.09 & 0.03 & - \\
\hline & $p$-Value & & 0.08 & 0.16 & 0.12 & 0.32 & - \\
\hline \multicolumn{8}{|c|}{ Linear contrast } \\
\hline \multicolumn{3}{|c|}{ "Mycotoxin": T-1, T-2 vs. T-3, T-4, T-5 } & 0.98 & 0.06 & 0.27 & 0.34 & - \\
\hline \multirow{2}{*}{\multicolumn{3}{|c|}{ "3 g/ kg additive": T-1, T-3 vs. T-2, T-5 }} & 0.19 & 0.39 & 0.77 & 0.40 & - \\
\hline & & & 0.62 & 0.59 & 0.07 & 0.90 & - \\
\hline
\end{tabular}

\footnotetext{
${ }^{1}$ MMDA, mycotoxin binder; ${ }^{2}$ RW, relative weight; ${ }^{3}$ scoring used for oral lesions evaluation: Grade 0 — without lesions. Grade 1 - color of the tongue ash or black. Grade 2-lesions with white-yellow plaques; lesions outside buccal cavity (beak, crest, wattle, and eyelids). Grade 3 - necrotic points, lesions inside buccal cavity (buccal cavity, tongue, tongue papillae, pores of saliva glands). Grade 4 -lesions in and outside of cavity; ${ }^{4}$ OTA, ochratoxin A; ${ }^{5}$ SEM, standard error of mean $(n=12)$.
}

\subsection{Intestinal Content $\mathrm{pH}$ and Intestinal Morphometry}

The values of intestinal content $\mathrm{pH}$ and intestinal morphometry parameters are reported in Table 9. No statistically significant differences were found among treatments irrespective to the method used for intestinal $\mathrm{pH}$ measurement (in situ or in an aqueous dilution). No significant differences among treatments were observed for any of the villus height, crypt depth, and the ratio of villus height to crypt depth $(p>0.05)$.

Table 9. The effects of feeding ochratoxin A (OTA) and T-2 mycotoxins and the addition of a binder mycotoxin product (MMDA) on intestinal $\mathrm{pH}$ and morphometry in broiler chickens.

\begin{tabular}{cccccccc}
\hline Treatment & Mycotoxins (mg/kg) & $\begin{array}{c}\text { MMDA } \\
(\mathbf{g} / \mathbf{k g})\end{array}$ & $\begin{array}{c}\text { Intestinal } \\
\mathbf{p H}^{\mathbf{2}}\end{array}$ & $\begin{array}{c}\text { Intestinal } \\
\mathbf{p H}^{\mathbf{3}}\end{array}$ & $\begin{array}{c}\text { Villus } \\
\text { Height } \\
(\boldsymbol{\mu} \mathbf{m})\end{array}$ & $\begin{array}{c}\text { Crypt Depth } \\
(\boldsymbol{\mu} \mathbf{m})\end{array}$ & $\begin{array}{c}\text { Villus } \\
\text { Height/Crypt } \\
\text { Depth }\end{array}$ \\
\hline T-1 & Non-contaminated & 0 & 6.46 & 7.01 & 928 & 128 & 7.76 \\
T-2 & Non-contaminated & 3 & 6.30 & 6.90 & 959 & 124 & 7.96 \\
T-3 & 0.5 OTA 4 + 1 T-2 & 0 & 6.48 & 6.93 & 913 & 123 & 7.59 \\
T-4 & 0.5 OTA + 1 T-2 & 1 & 6.36 & 6.89 & 918 & 123 & 7.75 \\
T-5 & 0.5 OTA + 1 T-2 & 3 & 6.53 & 7.00 & 937 & 128 & 7.52 \\
\hline
\end{tabular}


Table 9. Cont

\begin{tabular}{|c|c|c|c|c|c|c|c|}
\hline Treatment & Mycotoxins (mg/kg) & $\begin{array}{c}\text { MMDA }^{1} \\
(\mathrm{~g} / \mathrm{kg})\end{array}$ & $\begin{array}{c}\text { Intestinal } \\
\mathrm{pH}^{2}\end{array}$ & $\begin{array}{c}\text { Intestinal } \\
\mathrm{pH}^{3}\end{array}$ & $\begin{array}{l}\text { Villus } \\
\text { Height } \\
(\mu \mathrm{m})\end{array}$ & $\begin{array}{c}\text { Crypt Depth } \\
(\mu \mathrm{m})\end{array}$ & $\begin{array}{c}\text { Villus } \\
\text { Height/Crypt } \\
\text { Depth }\end{array}$ \\
\hline \multicolumn{3}{|c|}{ SEM $^{5}$} & 0.51 & 0.43 & 32.6 & 5.8 & 0.289 \\
\hline \multirow{2}{*}{\multicolumn{3}{|c|}{$p$-Value }} & 0.50 & 0.81 & 0.87 & 0.94 & 0.85 \\
\hline & & & \multicolumn{2}{|c|}{ Linear contrast } & & & \\
\hline \multicolumn{3}{|c|}{ "Mycotoxin": T-1, T-2 vs. T-3, T-4, T-5 } & 0.41 & 0.81 & 0.49 & 0.80 & 0.38 \\
\hline \multicolumn{3}{|c|}{ "3 g/kg additive": T-1, T-3 vs. T-2, T-5 } & 0.58 & 0.83 & 0.41 & 0.93 & 0.83 \\
\hline \multicolumn{3}{|c|}{ "Additive": T-3 vs. T-4, T-5 } & 0.75 & 0.91 & 0.72 & 0.65 & 0.90 \\
\hline
\end{tabular}

${ }^{1}$ MMDA, mycotoxin binder; ${ }^{2}$ intestinal $\mathrm{pH}$ measured directly in distal part of jejunum; ${ }^{3}$ intestinal $\mathrm{pH}$ measured on a $1 / 10$ dilution of jejunum content; ${ }^{4}$ OTA, ochratoxin A; ${ }^{5}$ SEM, standard error of mean $(n=12)$;

\section{Discussion}

Due to their constant occurrence in livestock feeds and their toxicity in animals, including poultry species, the evaluation of the toxicity of OTA and T-2 toxin in broiler chickens feed and its detoxification, by using a detoxifying agent, is considered very important. In the current research, contaminated diet with OTA and T-2 toxin (T-3) reduced significantly the BWG of broilers, the feed intake and impaired the FCR. Similarly, García et al. [17], using the same doses as the present study, demonstrated that broiler chickens fed $0.567 \mathrm{mg} / \mathrm{kg}$ of OTA and $0.927 \mathrm{mg} / \mathrm{kg}$ of T-2 toxin had a lower body weight and feed intake reduction. The dose of OTA used here $(0.5 \mathrm{mg} / \mathrm{kg}$ feed $)$ was higher than the guidance value $(0.1 \mathrm{mg} / \mathrm{kg}$ feed) set by the European Commission [4]. Therefore, this dose was high enough to cause detrimental effects in gain weight, feed intake and feed conversion ratio. The feeding of OTA $(0.25 \mathrm{mg} / \mathrm{kg}$ feed $)$ and T-2 toxin $(0.5 \mathrm{mg} / \mathrm{kg}$ feed $)$ decreased the body weights and feed consumption of chickens [16]. Kubena et al. [16] reported that broiler chickens fed OTA-T-2 diets ( 2 and $4 \mathrm{mg} / \mathrm{kg}$ feed) depressed the body weight of chickens and impaired the feed conversion ratio. The observed growth depression in mycotoxins-treated chicks may be due to the inhibition of protein synthesis followed by secondary disruption of RNA and DNA synthesis provoked by both mycotoxins [16]. Furthermore, this depression may be due to inflammation, contact erosion, and irritation of gastrointestinal tract, resulting into decrease in feed consumption and, consequently, in a decrease in body weight of chickens fed mycotoxins [29]. Interestingly, the toxin binder significantly counteracted the adverse effect of mycotoxins in performance.

Performance results did not reach the goals stated by the Aviagen company for male broiler chicken Ross 308 [24] under good management and environmental conditions when feeding pelleted diets with adequate nutrient levels, probably due to the supply of feeds in mash form, and the allocation of the animals in cages.

Concentrations of blood proteins and albumin in serum were lower in chickens fed OTA and T-2 toxin compared to control chickens. As described by Kubena et al. [16] and Wang et al. [18], the concentrations of proteins and albumin significantly decreased by the combination of OTA and T-2 toxin. This agrees with the study of Pozzo et al. [10], in which the blood proteins and albumin of intoxicated chickens $(0.1 \mathrm{mg}$ OTA $/ \mathrm{kg}$ feed) significantly decreased. Mnafi et al. [30] also reported a significant decrease in the blood proteins and albumin of chickens fed $0.5 \mathrm{mg} / \mathrm{kg}$ T-2 for 5 weeks. The results of the current study on the serum total proteins and albumin may reflect liver function, as OTA is known to impair hepatic protein synthesis [8]. In addition, the decrease in the blood proteins and albumin levels may be due to the degeneration of endoplasmic reticulum and the inhibition of protein synthesis in the hepatocytes, as T-2 toxin is a known inhibitor of eukaryotic protein synthesis by impairing initiation and termination steps of protein synthesis [16]. On the other hand, a possible increased protein elimination mechanism and renal leakage of albumin induced by OTA through the kidneys could be involved [9]. The inclusion of $3 \mathrm{~g}$ of MMDA mycotoxin binder $/ \mathrm{kg}$ feed mitigated the deleterious effects on these biochemical 
parameters, suggesting the efficacy of this product in reverting the disorders of hepatic protein synthesis.

Monocytes are a type of white blood cell produced in the bone marrow that enter the blood, and migrate to tissues (the spleen, liver, lung, and bone marrow), where they become macrophages. Monocytes are part of the innate immune system, and are related to the processes of intestinal inflammation, which in the case of chickens results in lower productivity. A significant reduction in the number of monocytes was also observed as the level of the additive increased. The inclusion of the additive in the mycotoxin contaminated feed, led to a reduction in the number of monocytes that could indicate less intestinal inflammation, which would represent a beneficial effect for chickens. It has been described that subcutaneous OTA exposure increased levels of monocytes in broiler chickens [31]. Other blood parameters were not affected by dietary treatments. Several researchers have reported that $\mathrm{H} / \mathrm{L}$ can be used as a good hematological indicator of stress response in chickens [32]. In the present study, the mycotoxin-contaminated diet did not affect the H/L ratio, speculating that OTA and T-2 mycotoxins at levels used did not cause suppression of hematopoiesis in the bone marrow. Similar results were reported by Pozzo et al. [10], as most of the hematological parameters were not affected by an OTA contaminated diet.

The reduction of the breast meat observed in broilers fed contaminated diets with mycotoxins is a direct result of the reduction of broilers body weights. Additionally, this reduction may be due to the possible carry-over of these mycotoxins, particularly OTA, to the muscle, as a consequence of contaminated feed ingestion. Due to the carry-over from feed, OTA has been widely reported to occur in meat and meat by-products [3]. In chickens exposed to $0.5 \mathrm{mg}$ of OTA/animal weekly for four weeks, OTA was found at 0.28 and $0.20 \mathrm{ng} / \mathrm{g}$ in breast and thigh muscle, respectively, after the first two weeks of exposure. After four weeks, OTA residue in muscle increased slightly, reaching its maximum value $(0.84 \mathrm{ng} / \mathrm{g}$ in both white and red muscles) [2].

Moreover, it was reported that OTA or T-2 mycotoxin could affect the immune system by the atrophy of the lymphoid organs along with depletion of lymphocytes and the enlargement of the kidney and liver $[9,13,31]$. However, in the current research, the combination of OTA and T-2 mycotoxin at levels examined in broilers feed did not affect the relative weights of liver, gizzard, kidneys, and spleen $(p>0.05)$. It was reported that feeding broiler chickens $0.1 \mathrm{mg} / \mathrm{kg}$ OTA in diet did not affect relative weights of liver, kidney and bursa of Fabricius [33]. Furthermore, no significant differences in the relative weights of bursa of Fabricius and spleen were found in broilers exposed to $2 \mathrm{mg} / \mathrm{kg}$ of OTA and $3 \mathrm{mg} / \mathrm{kg}$ of T-2 toxin [29]. Therefore, it can be concluded that the reported effects of dietary OTA and T-2 toxin on relative organ weights in poultry are very inconsistent across studies.

The occurrence and severity of the oral lesions appear to reflect the effect of T-2 toxin [16]. It has been observed in chickens who received $2 \mathrm{mg} / \mathrm{kg} \mathrm{T}-2$ toxin, leading to loss of body weight [34]. Nevertheless, under current experimental conditions, no oral lesions have been found. In terms of oral lesions, chickens may be relatively resistant to the effects of T-2 mycotoxin, when the concentration in the feed does not exceed $1 \mathrm{mg} / \mathrm{kg}$. Moreover, it should be noted that the feeding of chickens with contaminated diets containing $2 \mathrm{mg}$ of OTA $/ \mathrm{kg}$ of feed did not produce any change in oral lesions scores [35].

The gastrointestinal tract is the site of nutrient digestion and absorption and is a target organ of mycotoxicosis. It has been found that several mycotoxins, including OTA and T-2 mycotoxin, result in histological changes in broilers intestines such as shortened, atrophied and thin villi, and elongated crypts with irregular forms, indicative that these mycotoxins can alter the digestive tract and the absorption function [36]. However, in the present study, the combination of OTA and T-2 mycotoxin at levels tested in broilers feed did not affect villus height and crypt depth. Similar results have been observed in broilers fed other mycotoxins, such as DON [37]. 


\section{Conclusions}

Based on the results of the present study, the ingestion of OTA and T-2 toxin adversely affected the productive parameters and some blood and carcass characteristics of broiler chickens. The addition of the MMDA detoxifying agent at $1 \mathrm{or} 3 \mathrm{~g} / \mathrm{kg}$ feed in contaminated diets improved performance, mainly in the finisher period (from 21-35 days), and was partly capable of counteracting the deleterious effects of these mycotoxins. In particular, the simultaneous presence of OTA and T2 toxin significantly reduced the BWG of broilers, the feed intake and impaired the FCR during the finished period. Broiler chickens fed mycotoxin contaminated feed showed lower serum concentrations of blood proteins and albumin were lower in chickens fed the mycotoxins compared to control chickens, which may reflect an impairment of hepatic protein synthesis. The inclusion of $3 \mathrm{~g}$ of MMDA mycotoxin binder $/ \mathrm{kg}$ feed mitigated the deleterious effects on these biochemical parameters, suggesting the efficacy of this product in reverting the disorders of hepatic protein synthesis.

Author Contributions: Conceptualization: J.R., A.M.P.-V. and A.J.R.; methodology: A.M.P.-V. and J.R.; software: A.M.P.-V.; validation: J.R.; formal analysis: I.R. and A.M.P.-V.; investigation: A.M.P.-V., A.J.R. and J.R.; resources: J.R. and A.M.P.-V.; data curation: A.M.P.-V.; writing-original draft preparation: I.R.; writing-review and editing: I.R., A.J.R., J.R. and A.M.P.-V.; visualization: J.R., A.M.P.-V., A.J.R. and I.R.; supervision: J.R., A.J.R. and A.M.P.-V.; project administration: J.R.; funding acquisition, M.V., mycotoxin production for this trial: Z.J., mycotoxin's analysis: H.F. All authors have read and agreed to the published version of the manuscript.

Funding: This research was funded by Patent Co., Vlade Ćetkovića 1A, 24211 Mišićevo, Serbia.

Institutional Review Board Statement: The study was conducted according to the current regulations on the use and handling of experimental animals (decree 214/97, Generalitat de Catalunya, Catalonia, Spain) and was approved by the Ethical Committee for Animal Experimentation of the Institute of Agrifood Research and Technology (IRTA) (Number 10625/03/09/2019).

Data Availability Statement: All data sets collected and analyzed during the current study are available from the corresponding author upon fair request.

Conflicts of Interest: The authors declare no conflict of interest.

\section{References}

1. Smith, M.-C.; Madec, S.; Coton, E.; Hymery, N. Natural Co-Occurrence of Mycotoxins in Foods and Feeds and Their in vitro Combined Toxicological Effects. Toxins 2016, 8, 94. [CrossRef]

2. Battacone, G.; Nudda, A.; Pulina, G. Effects of Ochratoxin A on Livestock Production. Toxins 2010, 2, 1796-1824. [CrossRef] [PubMed]

3. Tolosa, J.; Ruiz, M.J.; Ferrer, E.; Vila-Donat, P. Ochratoxin A: Occurrence and carry-over in meat and meat by-products. A review. Rev. Toxicol. 2020, 37, 106-110.

4. Kyprianou, M. European Commission Commission Recommendation of 17 August 2006 on the presence of deoxynivalenol, zearalenone, ochratoxin A, T-2 and HT-2 and fumonisins inproducts intended for animal feeding. Off. J. Eur. Union 2006, L299, 7-9.

5. Galtier, P.; Alvinerie, M.; Charpenteau, J. The pharmacokinetic profiles of ochratoxin A in pigs, rabbits and chickens. Food Cosmet. Toxicol. 1981, 19, 735-738. [CrossRef]

6. Hamilton, P.B.; Huff, W.E.; Harris, J.R.; Wyatt, R.D. Natural Occurrences of Ochratoxicosis in Poultry. Poult. Sci. 1982, 61, 1832-1841. [CrossRef]

7. Elaroussi, M.; Mohamed, F.; El Barkouky, E.; Atta, A.; Abdou, A.; Hatab, M. Experimental ochratoxicosis in broiler chickens. Avian Pathol. 2006, 35, 263-269. [CrossRef] [PubMed]

8. Stoev, S.D.; Djuvinov, D.; Mirtcheva, T.; Pavlov, D.; Mantle, P. Studies on some feed additives giving partial protection against ochratoxin A toxicity in chicks. Toxicol. Lett. 2002, 135, 33-50. [CrossRef]

9. Elaroussi, M.; Mohamed, F.; Elgendy, M.; El Barkouky, E.; Abdou, A.; Hatab, M. Ochratoxicosis in Broiler Chickens: Functional and Histological Changes in Target Organs. Int. J. Poult. Sci. 2008, 7, 414-422. [CrossRef]

10. Pozzo, L.; Cavallarin, L.; Antoniazzi, S.; Guerre, P.; Biasibetti, E.; Capucchio, M.T.; Schiavone, A. Feeding a diet contaminated with ochratoxin A for broiler chickens at the maximum level recommended by the EU for poultry feeds $(0.1 \mathrm{mg} / \mathrm{kg})$. 2 . Effects on meat quality, oxidative stress, residues and histological traits. J. Anim. Physiol. Anim. Nutr. 2013, 97, 23-31. [CrossRef] 
11. Zhai, S.; Zhu, Y.; Frng, P.; Li, M.; Wang, W.; Yang, L.; Yang, Y. Ochatoxin A: Its impact on poultry health and microbiota, an overview. Poult. Sci. 2021, 100, 101037. [CrossRef] [PubMed]

12. Wyatt, R.D.; Hamilton, P.B.; Burmeister, H.R. The effects of T-2 toxin in broiler chickens. Poult. Sci. 1973, 52, 1853-1859. [CrossRef] [PubMed]

13. Sokolović, M.; Garaj-Vrhovac, V.; Šimpraga, B. T-2 Toxin: Incidence and Toxicity in Poultry. Arch. Ind. Hyg. Toxicol. 2008, 59, 43-52. [CrossRef] [PubMed]

14. EFSA Panel on Contaminants in the Food Chain (CONTAM). Scientific Opinion on the risks for animal and public health related to the presence of T-2 and HT-2 toxin in food and feed. EFSA J. 2011, 9, 2481. [CrossRef]

15. Yin, H.; Han, S.; Chen, Y.; Wang, Y.; Li, D.; Zhu, Q. T-2 Toxin Induces Oxidative Stress, Apoptosis and Cytoprotective Autophagy in Chicken Hepatocytes. Toxins 2020, 12, 90. [CrossRef]

16. Kubena, L.; Huff, W.; Harvey, R.; Phillips, T.; Rottinghaus, G. Individual and Combined Toxicity of Deoxynivalenol and T-2 Toxin in Broiler Chicks. Poult. Sci. 1989, 68, 622-626. [CrossRef]

17. García, A.R.; Avila, E.; Rosiles, R.; Petrone, V.M. Evaluation of Two Mycotoxin Binders to Reduce Toxicity of Broiler Diets Containing Ochratoxin A and T-2 Toxin Contaminated Grain. Avian Dis. 2003, 47, 691-699. [CrossRef]

18. Wang, G.H.; Xue, C.Y.; Chen, F.; Ma, Y.L.; Zhang, X.B.; Bi, Y.Z.; Cao, Y.C. Effects of combinations of ochratoxin A and T-2 toxin on immune function of yellow-feathered broiler chickens. Poult. Sci. 2009, 88, 504-510. [CrossRef]

19. Xue, C.Y.; Wang, G.H.; Chen, F.; Zhang, X.B.; Bi, Y.Z.; Cao, Y.C. Immunopathological effects of ochratoxin A and T-2 toxin combination on broilers. Poult. Sci. 2010, 89, 1162-1166. [CrossRef]

20. Tsiouris, V.; Tassis, P.; Raj, J.; Mantzios, T.; Kiskinis, K.; Vasiljević, M.; Delić, N.; Petridou, E.; Brellou, G.; Polizopoulou, Z.; et al. Investigation of a Novel Multicomponent Mycotoxin Detoxifying Agent in Amelioration of Mycotoxicosis Induced by AflatoxinB1 and Ochratoxin A in Broiler Chicks. Toxins 2021, 13, 367. [CrossRef]

21. Rajendran, R.M.; Umesh, B.; Chirakkal, H. Assessment of H- $\beta$ zeolite as an ochratoxin binder for poultry. Poult. Sci. 2020, 99, 76-88. [CrossRef]

22. Vartiainen, S.; Yiannikouris, A.; Apajalahti, J.; Moran, C.A. Comprehensive Evaluation of the Efficiency of Yeast Cell Wall Extract to Adsorb Ochratoxin A and Mitigate Accumulation of the Toxin in Broiler Chickens. Toxins 2020, 12, 37. [CrossRef] [PubMed]

23. Raj, J.; Vasiljević, M.; Tassis, P.; Farkaš, H.; Männer, K. Efficacy of a multicomponent mycotoxin detoxifying agent on concurrent exposure to zearalenone and T-2 mycotoxin in weaned pigs. Livest. Sci. 2020, 242, 104295. [CrossRef]

24. Aviagen Ross 308 Broiler: Nutrition Specifications 2019. Available online: https://es.aviagen.com/brands/ross/products/ross308 (accessed on 9 November 2021).

25. Riahi, I.; Marquis, V.; Pérez-Vendrell, A.M.; Brufau, J.; Esteve-Garcia, E.; Ramos, A.J. Effects of Deoxynivalenol-Contaminated Diets on Metabolic and Immunological Parameters in Broiler Chickens. Animals 2021, 11, 147. [CrossRef] [PubMed]

26. Morgan, N.K.; Walk, C.L.; Bedford, M.R.; Burton, E. The effect of dietary calcium inclusion on broiler gastrointestinal pH: Quantification and method optimization. Poult. Sci. 2014, 93, 354-363. [CrossRef] [PubMed]

27. Pang, Y.; Applegate, T.J. Effects of Dietary Copper Supplementation and Copper Source on Digesta pH, Calcium, Zinc, and Copper Complex Size in the Gastrointestinal Tract of the Broiler Chicken. Poult. Sci. 2007, 86, 531-537. [CrossRef] [PubMed]

28. Nofrarías, M.; Manzanilla, E.G.; Pujols, J.; Gibert, X.; Majo, N.; Segalés, J.; Gasa, J. Effects of spray-dried porcine plasma and plant extracts on intestinal morphology and on leukocyte cell subsets of weaned pigs1. J. Anim. Sci. 2006, 84, 2735-2742. [CrossRef] [PubMed]

29. Pande, V.V.; Kurkure, N.V.; Bhandarkar, A.G. Effect of T-2 toxin on growth, performance and haematobiochemical alterations in broilers. Indian J. Exp. Boil. 2006, 44, 86-88.

30. Manafi, M.; Pirany, N.; Ali, M.N.; Hedayati, M.; Khalaji, S.; Yari, M. Experimental pathology of T-2 toxicosis and mycoplasma infection on performance and hepatic functions of broiler chickens. Poult. Sci. 2015, 94, 1483-1492. [CrossRef]

31. Khan, S.A.; Venancio, E.J.; Ono, M.A.; Fernandes, E.V.; Hirooka, E.Y.; Shimizu, C.F.; Oba, A.; Flaiban, K.K.M.C.; Itano, E.N. Effects of Subcutaneous Ochratoxin-A Exposure on Immune System of Broiler Chicks. Toxins 2019, 11, 264. [CrossRef]

32. Gross, W.B.; Siegel, H.S. Evaluation of the Heterophil/Lymphocyte Ratio as a Measure of Stress in Chickens. Avian Dis. 1983, 27, 972. [CrossRef] [PubMed]

33. Singh, R.; Mandal, A.B.; Sharma, M.; Biswas, A. Effect of varying levels of dietary ochratoxin a on the performance of broiler chickens. Indian J. Anim. Sci. 2015, 85, 296-300.

34. Nesic, K.; Resanovic, R.; Jakic-Dimic, D.; Nesic, V. Efficiency of various feed additives on the performance of broilers treated with T-2 toxin. Biotehnol. Anim. Husb. 2011, 27, 705-711. [CrossRef]

35. Kubena, L.F.; Harvey, R.B.; Edrington, T.S.; Rottinghaus, G.E. Influence of Ochratoxin A and Diacetoxyscirpenol Singly and in Combination on Broiler Chickens. Poult. Sci. 1994, 73, 408-415. [CrossRef]

36. Ruan, D.; Wang, W.C.; Lin, C.X.; Fouad, A.M.; Chen, W.; Xia, W.G.; Wang, S.; Luo, X.; Zhang, W.H.; Yan, S.J.; et al. Effects of curcumin on performance, antioxidation, intestinal barrier and mitochondrial function in ducks fed corn contaminated with ochratoxin A. Animals 2019, 13, 42-52. [CrossRef]

37. Riahi, I.; Marquis, V.; Ramos, A.J.; Brufau, J.; Esteve-Garcia, E.; Pérez-Vendrell, A.M. Effects of Deoxynivalenol-Contaminated Diets on Productive, Morphological, and Physiological Indicators in Broiler Chickens. Animals 2020, 10, 1795. [CrossRef] 